\title{
Patterns of turnover and floristic similarity show a non-random distribution of naturalized flora in Chile, South America
}

\author{
Patrones de recambio y similitud florística muestran una distribución no aleatoria \\ de la flora naturalizada en Chile, Sudamérica
}

SERGIO A. CASTRO ${ }^{1,3 *}$ \& FABIÁN M. JAKSIC ${ }^{2,3}$

\author{
${ }^{1}$ Departamento de Biología, Facultad de Química y Biología, Universidad de Santiago de Chile \\ ${ }^{2}$ Departamento de Ecología, Facultad de Ciencias Biológicas, Pontificia Universidad Católica de Chile \\ ${ }^{3}$ Center for Advanced Studies in Ecology \& Biodiversity (CASEB), Pontificia Universidad Católica de Chile, \\ CP 6513677, Santiago, Chile \\ *e-mail for correspondence: scastro@usach.cl
}

\begin{abstract}
The current geographical distribution of alien species could be informative of processes involved in the biological invasions facilitated by humans. Because environmental and anthropic factors affect the geographic distribution of alien plants, we hypothesize that naturalized plants have a non-random distribution along extensive geographical ranges. On the basis of a complete and updated database of naturalized plants in Chile, we analyzed their turnover and floristic similarities among regions that encompass a wide latitudinal gradient in South America. Using Moran's index and Mantel's test we characterized the spatial auto-correlation (regional aggregation) and the effect of geographical distance on the index values. Additionally, we used clustering methods and resampling procedures to detect plant assemblages at regional level. Whittaker's index displayed a positive tilt, increasing according to geographical distance and reaching a plateau; conversely, Jaccard's index was negatively associated with geographical distance. Removing the effect of distance, both Whittaker's and Jaccard's values showed no significant trends. Multivariate analysis combined with resampling procedures revealed the existence of three distinctive plant clusters: Northernmost Chile, Centralsouthern Chile, and Southernmost Chile. These clusters are characterized by naturalized plants that are not present in the others. Based on this evidence, we conclude that the set of naturalized plants in Chile exhibits a non-random geographical distribution, displaying an ordered geographical pattern across regions (latitude). We discuss the role of the environmental variables (climate, latitude) and land use post-European colonization as factors in the distributional patterns here documented.
\end{abstract}

Key words: Jaccard's index, Whittaker's index, plant invasions, naturalized plants, similarity, turnover.

\section{RESUMEN}

La distribución geográfica actual de especies exóticas puede ser informativa de los procesos involucrados en las invasiones biológicas facilitadas por humanos. Debido a que los factores ambientales y antrópicos pueden afectar la distribución geográfica de plantas exóticas, hipotetizamos que las plantas naturalizadas deberían exhibir una distribución no aleatoria. Utilizando una actualizada y completa base de datos de la distribución geográfica de plantas naturalizadas en Chile, analizamos los patrones de recambio (índice de Whittaker) y similitud florística (índice de Jaccard) entre regiones, las que cubren un amplio gradiente latitudinal en Sudamérica. Usando el índice de Moran y pruebas de Mantel, caracterizamos el nivel de autocorrelación espacial y el efecto de la distancia geográfica. Además, utilizamos métodos de aglomeración y procedimientos de remuestreo para detectar conglomerados florísticos a nivel regional. El índice de Whittaker mostró una relación positiva y asintótica en función de la distancia geográfica entre regiones; inversamente, el índice de Jaccard mostró una relación negativa con la distancia geográfica. Removiendo el efecto de la distancia, ninguno de los índices mostró tendencia significativa con la distancia geográfica. El análisis de conglomerados reveló la presencia de tres conglomerados florísticos regionales, localizados en el extremo norte, segmento centro-sur y extremo sur de Chile. En base a esta evidencia, concluimos que la distribución geográfica de plantas naturalizadas en Chile se encuentra geográficamente ordenada. Discutimos el presunto papel de la historia humana y el gradiente climático como factores determinantes de este patrón.

Palabras clave: índice de Jaccard, índice de Whittaker, invasiones biológicas, plantas naturalizadas, similitud, recambio. 


\section{INTRODUCTION}

The human impact on ecosystems is progressively modifying the distributional patterns of many taxa (Vitousek 1992, Chapin III et al. 2000, Sala et al. 2000). Basically, humans disrupt geographical barriers and affect the geographical range of species (McKinney \& Lockwood 1999). As a result, many species have become extinct (in which case their range has been reduced to zero), or relocated in which case their range has been increased tremendously (McKinney \& Lockwood 1999, Sax \& Gaines 2003). Because of its massive occurrence and direct effects on biodiversity, human-assisted species invasions are considered a main factor in biotic change at global and regional scales (Vitousek 1992, Vitousek et al. 1996, Chapin III et al. 2000, Sala et al. 2000). Nevertheless, there is scarce quantitative evidence about the mode (rates, pathways, and symmetries in biotic interchanges) and trends by which the biotic scenario is changing (McNeeley 2001, Vermeij 2005, Olden 2006). The characterization of anthropically-driven biological invasions may contribute to improve our understanding of the role of humans in biotic change scenarios (Chapin et al. 2000, Sala et al. 2000).

Similarly as geographical distribution of native species contributes to identifying evolutionary, biogeographical and macroecological processes (Brown \& Lomolino 1998, Blackburn \& Gaston 2003, Wiens \& Donoghue 2004), the current geographical distribution of alien species should be informative about the characteristics of biotic interchange facilitated by humans and the processes that affect the spread of alien species (Mack et al. 2000, Sax 2001, Drake \& Lodge 2004, McKinney 2004b, Rouget et al. 2004). In this vein, most studies document gradients of richness of alien species in connection to human settlements (Klotzs 1990, Lonsdale 1999, Rapoport 2000, Sax et al. 2002, Deutschewitz et al. 2003, Rouget et al. 2004), and little attention has been paid to the detection of turnover patterns and distributional arrangements (Rejmánek 2000, McKinney 2004a, 2004b, 2005). These two approaches differ in that they emphasize different aspects of biodiversity change, namely, number and taxonomic identity.
At a geographical scale, a non-random distribution of alien species may be expected for two reasons. First, alien species respond to climatic and geographic variables that may constrain their distributional ranges (Guisan \& Zimmermann 2000, Sax 2001), this being a basic axiom in predictive models of alien distribution based on environmental variables (Loehle \& de Blanc 1996, Guisan \& Zimmermann 2000). Therefore, alien species with similar constraints may show similar patterns of distribution, determining the emergence of spatial ordering. Second, because alien species usually spread according to land occupation by humans, current distributional patterns may reveal such tracking (Mack et al. 2000, Kowarik 2003, Drake \& Lodge 2004).

Here, we analyze the patterns of geographical distribution of alien plants conformed by a representative set of naturalized species in Chile. Specifically, we characterize the turnover and similarity patterns among adjoining regions, under the hypothesis that a non-random distribution of naturalized flora should be found along the geographical scale chosen. Because continental Chile comprises a broad latitudinal and climatic gradient (Fig. 1), closely associated to different land-use and colonization history of its regions, we expect to recognize distinct floristic assemblages made up by naturalized plants.

\section{MATERIAL AND METHODS}

\section{Geographic areas}

Continental Chile lies along the southwestern coast of South America, between latitudes $17^{\circ} 30^{\prime}$ and $56^{\circ} 30^{\prime} \mathrm{S}$ and longitudes $68^{\circ}$ to $72^{\circ}$ W. It extends as a narrow belt of land 4,270 $\mathrm{km}$ long, comprising a broad north-south latitudinal gradient, covering an area of approximately $756,626 \mathrm{~km}^{2}$. Politically, the country is divided into 13 administrative regions (Fig. 1), all sequentially laid southwards along the territory, and identified with numbers I to XII, and acronym MR for Metropolitan Region, which is landlocked between Regions V and VI in the central part of the territory (Fig. 1, Table 1). 


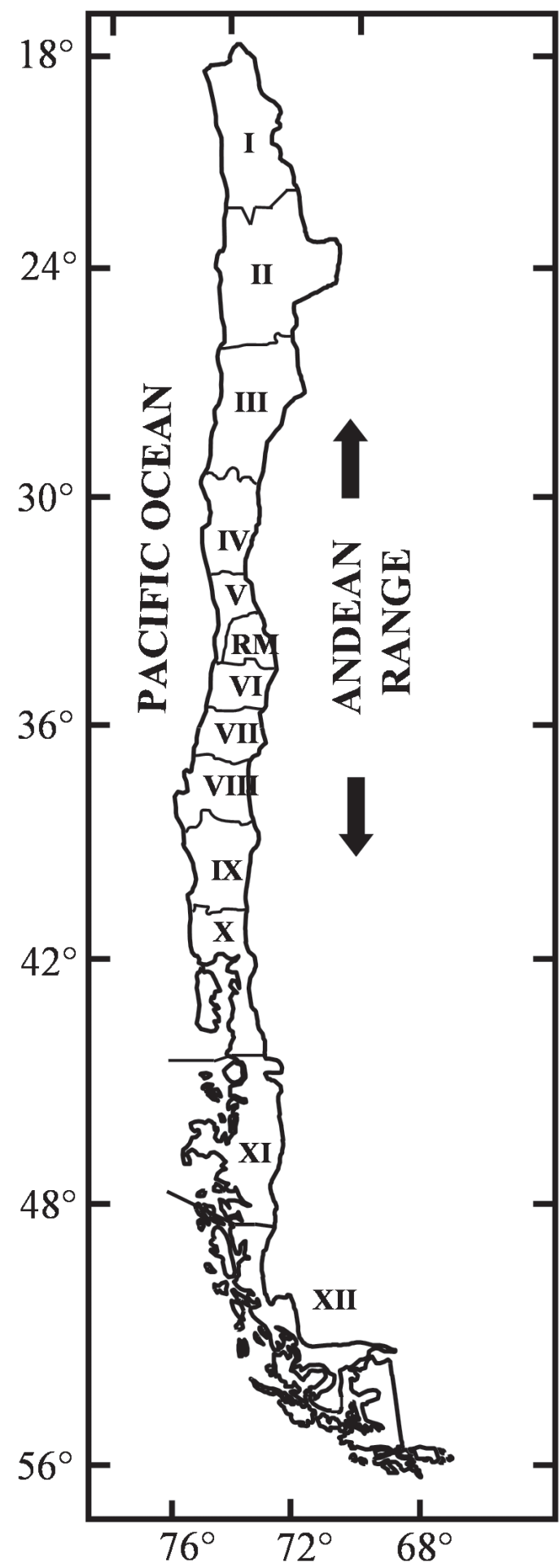

Fig. 1: Geopolitical map of continental Chile. The regions correspond to 13 administrative regions (numbered I to XII plus Metropolitan Region).

Mapa geopolítico de Chile continental. Las regiones corresponden a las 13 regiones administrativas (numeradas desde la I a la XII más la Región Metropolitana).
TABLE 1

Area and geographic location of the thirteen administrative regions in Chile, based on Instituto Geografico Militar (1985)

Area y ubicación geográfica de las 13 regiones administrativas en Chile, en base a Instituto Geografico Militar (1985)

\begin{tabular}{lcc}
\hline Regions & Area $\left(\mathrm{km}^{2}\right)$ & Geographic coordinates \\
\hline Region I & 58,073 & $17^{\circ} 30^{\prime}$ ' to $21^{\circ} 39^{\prime} \mathrm{S}$ \\
Region II & 125,306 & $20^{\circ} 56^{\prime}$ ' to $26^{\circ} 05^{\prime} \mathrm{S}$ \\
Region III & 78,268 & $25^{\circ} 17^{\prime}$ ' to $29^{\circ} 11^{\prime} \mathrm{S}$ \\
Region IV & 39,647 & $29^{\circ} 02^{\prime}$ ' to $32^{\circ} 16^{\prime} \mathrm{S}$ \\
Region V & 16,109 & $32^{\circ} 02^{\prime}$ ' to $33^{\circ} 57^{\prime} \mathrm{S}$ \\
Metropolitan & & \\
Region (MR) & 13,807 & $32^{\circ} 55^{\prime}$ ' to $34^{\circ} 19^{\prime} \mathrm{S}$ \\
Region VI & 18,193 & $33^{\circ} 51^{\prime}$ 'to $35^{\circ} 01^{\prime} \mathrm{S}$ \\
Region VII & 30,518 & $34^{\circ} 41^{\prime}$ 'to $36^{\circ} 33^{\prime} \mathrm{S}$ \\
Region VIII & 36,824 & $36^{\circ} 00^{\prime}$ ' to $38^{\circ} 30^{\prime} \mathrm{S}$ \\
Region IX & 31,760 & $37^{\circ} 35^{\prime}$ 'to $39^{\circ} 37^{\prime} \mathrm{S}$ \\
Region X & 67,090 & $39^{\circ} 16^{\prime}$ 'to $44^{\circ} 04^{\prime} \mathrm{S}$ \\
Region XI & 108,998 & $43^{\circ} 38^{\prime}$ 'to $49^{\circ} 16^{\prime} \mathrm{S}$ \\
Region XII & 132,033 & $48^{\circ} 39^{\prime}$ 'to $56^{\circ} 30^{\prime} \mathrm{S}$ \\
\hline
\end{tabular}

\section{Assembling a database of naturalized flora}

We assembled an updated database for naturalized flora, describing its geographical distribution in Chile. We used the botanical and herbaria records that, in general terms, identify naturalized plants as those established species whose reproduction is carried out independently of human assistance (Pyšek 2004). The distributional information on plants was obtained from an exhaustive review of floristic studies, botanical collections, and herbarium deposits (Gay 1845-1854, Reiche 1896-1811, Marticorena et al. 1998, 2001; more details in Castro et al. 2005). For each plant species, we recorded its distribution among regions in Chile using a presence $(=1)$ or absence $(=0)$ code. We used administrative regions, and not smaller-scale localities, because many publications and botanical collections do not indicate locality or do so in vague terms. Thus, we maximized the volume of data available for our analytical purposes. 
An updated distributional record was obtained for 542 species of plants, equal to $68 \%$ of the naturalized flora recorded in Chile. In order to detect floristic turnover and similarity patterns we set up a species-area matrix (area = administrative regions), and then we calculated turnover and similarity among regions, obtaining two matrices. First, we examined the alien turnover using Whittaker's index $\mathrm{W}=(\mathrm{s} / \alpha)-1$, where $(S)$ is the number of species in two regions, and $(\alpha)$ is the mean number of species in the regions. Second, we calculated the level of similarity using Jaccard's index $J=\mathrm{c} /(\mathrm{a}+\mathrm{b}-\mathrm{c})$, where (a) is the number of species in a region, (b) is the number of species in another region, and (c) is the number of species common to both. The values of $J$ range between zero and one for complete dissimilarity to complete similarity, respectively.

Both matrices (turnover and similarity) were subjected to Mantel's and Moran's tests to detect the significant effects due to geographical distance and spatial aggregation (autocorrelation) of values (Webster \& Oliver 2001). For Mantel test, we used turnover and similarity among administrative regions versus the matrix of geographical distances among regions. Here, the distance used was the geographical separation between capitals of each region. For Moran test, we calculated spatial autocorrelation using Rooks criterion of contiguity on a regular lattice that assumes two borders in each region, except for Regions I and XII which had only one (Fig. 1).

To recognize characteristic floristic groups we constructed a phenogram using unweighted pair-group procedure (UPGMA) from the similarity matrix. UPGMA uses arithmetical averaging between the similarity indexes of different groups (McGarigal et al. 2000). For cluster recognition in the phenogram we conducted bootstrapping on the species-area matrix (Manly 1991), using 5,000 iterations and recomputing Jaccard's index among different regions in each opportunity. From the frequency distribution of pseudovalues we recognized the critical value for an index significant at $\mathrm{P}<0.05$. In this procedure, index values greater than such critical value $\left(J^{*}\right)$ are unlikely to arise from random processes (Manly 1991).
We obtained geographical distribution records for 542 naturalized plants in Chile. Of those, 541 species were Spermatophytes and only one was a Pteridophyte. Spermatophytes were split into 409 dicots and 132 monocots, with Poaceae (109 species), Asteraceae (90 species) and Fabaceae (42 species) being the most specious families. The bulk of naturalized species was recorded in the central region of Chile, whereas the northern and southern extremes contained only a minor proportion of naturalized plants (Fig. 2). In fact, the central regions contained between $35 \%$ and $60 \%$ of the naturalized species, while the extreme regions each concentrated $<21 \%$ of the species (Fig. 2). Significant differences existed in the frequency distribution of naturalized species among regions $(\mathrm{G}=5.3, \mathrm{P}<0.001)$; a similar distribution resulted when considering the density of species (No./Ln (area), $\mathrm{G}=26.6$, $\mathrm{P}<0.001)$.

\section{Turnover patterns}

Turnover patterns of naturalized plants in Chile are shown in Table 2. These values ranged from 1.19 to 1.83 . Moran's index showed a significant spatial auto-correlation in $\mathrm{W}$ values (Moran's I = 0.680, z-Normal $=2.8$ ), indicating aggregation according to administrative regions. In general terms, we recorded the lowest $\mathrm{W}$ values between adjacent regions while higher values were obtained with increasing geographical distance. In fact, the Mantel test showed a significant effect of geographical distance upon W (Fig. 3A), a relationship that reaches the highest correlation with the following function: $y=0.65 \mathrm{x}^{0.11}\left(\mathrm{r}^{2}=\right.$ $0.68, \mathrm{P}<0.001, \mathrm{n}=78)$. The graphic of the residuals (Fig. 3B), which removes the distance effect, shows a decrease of residual variance according to increasing distance, but this trend is not significant $\left(\mathrm{r}^{2}=0.0031\right)$.

\section{Similarity patterns}

The regional similarity $(100 \times J)$ ranged from 10.5 to $68.5 \%$ (Table 3 ). The higher $J$ values were obtained in central Chile and they showed a significant spatial auto-correlation (Moran's I $=0.676, \mathrm{z}-$ Normal $=2.8$ ). According to Mantel 


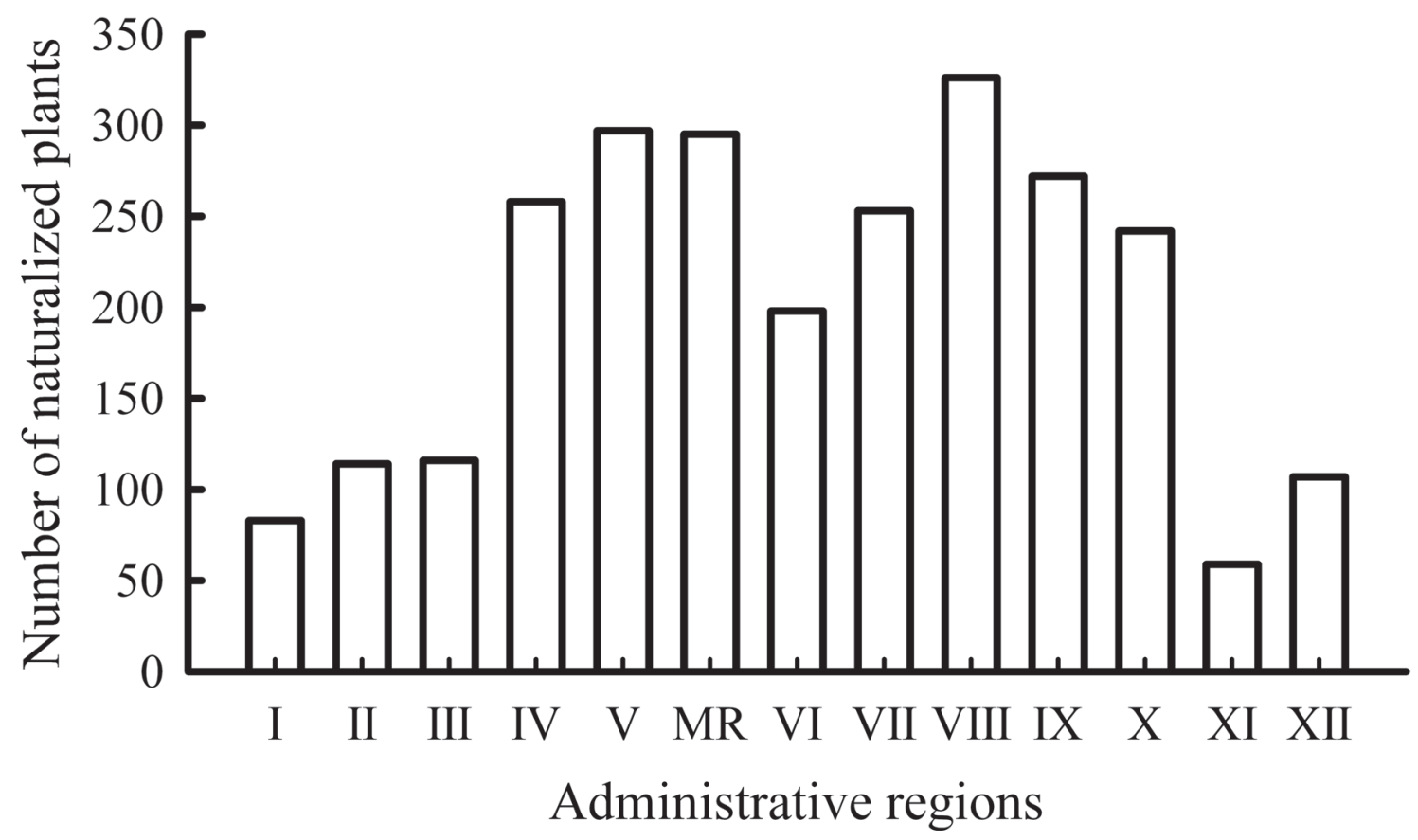

Fig. 2: Frequency distribution of the number of naturalized plants among administrative regions in Chile ( $\mathrm{n}=542$ species $)$.

Distribución de frecuencia del número de plantas naturalizadas en las regiones administrativas de Chile ( $\mathrm{n}=542$ especies).

TABLE 2

Compositional turnover (Whittaker's index, W) of the naturalized flora among administrative regions in Chile. These are numbered I to XII, plus Metropolitan Region (MR)

Recambio composicional (índice de Whittaker, W) de la flora naturalizada entre regiones administrativas de Chile. Las regiones han sido numeradas desde I a la XII, más la Región Metropolitana (MR)

\begin{tabular}{|c|c|c|c|c|c|c|c|c|c|c|c|c|}
\hline & II & III & IV & $\mathrm{V}$ & MR & VI & VII & VIII & IX & $\mathrm{X}$ & XI & XII \\
\hline I & 1.49 & 1.50 & 1.65 & 1.66 & 1.67 & 1.69 & 1.72 & 1.74 & 1.72 & 1.73 & 1.80 & 1.81 \\
\hline II & & 1.49 & 1.51 & 1.54 & 1.56 & 1.57 & 1.59 & 1.63 & 1.60 & 1.62 & 1.76 & 1.74 \\
\hline III & & & 1.46 & 1.53 & 1.53 & 1.58 & 1.60 & 1.63 & 1.63 & 1.62 & 1.83 & 1.81 \\
\hline IV & & & & 1.23 & 1.24 & 1.35 & 1.33 & 1.33 & 1.36 & 1.40 & 1.72 & 1.65 \\
\hline V & & & & & 1.19 & 1.31 & 1.28 & 1.23 & 1.28 & 1.32 & 1.73 & 1.65 \\
\hline $\mathrm{RM}$ & & & & & & 1.33 & 1.30 & 1.26 & 1.30 & 1.36 & 1.75 & 1.66 \\
\hline VI & & & & & & & 1.29 & 1.33 & 1.32 & 1.35 & 1.65 & 1.63 \\
\hline VII & & & & & & & & 1.23 & 1.25 & 1.30 & 1.70 & 1.62 \\
\hline VIII & & & & & & & & & 1.20 & 1.25 & 1.71 & 1.64 \\
\hline IX & & & & & & & & & & 1.22 & 1.68 & 1.60 \\
\hline$X$ & & & & & & & & & & & 1.65 & 1.56 \\
\hline XI & & & & & & & & & & & & 1.51 \\
\hline
\end{tabular}


TABLE 3

Compositional similarity (Jaccard's index, $100 \times J$ ) of the naturalized flora among administrative regions in Chile. These are numbered I to XII, plus Metropolitan Region (MR)

Similitud composicional (índice de Jaccard, $100 \times J$ ) de la flora naturalizada entre regiones administrativas de Chile. Las regiones han sido numeradas desde I a la XII, más la Región Metropolitana (MR)

\begin{tabular}{|c|c|c|c|c|c|c|c|c|c|c|c|c|}
\hline & II & III & IV & $\mathrm{V}$ & MR & VI & VII & VIII & IX & $\mathrm{X}$ & XI & XII \\
\hline I & 35.2 & 34.7 & 22.2 & 20.8 & 20.6 & 19.4 & 17.3 & 15.5 & 16.7 & 16.0 & 12.8 & 11.9 \\
\hline II & & 35.3 & 33.0 & 30.2 & 29.2 & 28.3 & 26.3 & 23.6 & 26.0 & 24.4 & 14.9 & 16.1 \\
\hline III & & & 37.5 & 31.6 & 31.4 & 27.5 & 25.7 & 23.5 & 23.4 & 23.8 & 10.5 & 11.3 \\
\hline IV & & & & 62.8 & 61.5 & 49.2 & 50.7 & 50.9 & 47.4 & 43.3 & 16.7 & 22.1 \\
\hline V & & & & & 68.5 & 52.8 & 57.3 & 63.7 & 56.7 & 51.5 & 16.6 & 21.6 \\
\hline $\mathrm{RM}$ & & & & & & 51.1 & 54.4 & 59.6 & 53.9 & 47.6 & 15.0 & 21.1 \\
\hline VI & & & & & & & 56.2 & 51.1 & 52.4 & 48.7 & 22.3 & 23.5 \\
\hline VII & & & & & & & & 62.9 & 60.0 & 54.9 & 18.5 & 24.4 \\
\hline VIII & & & & & & & & & 67.9 & 60.6 & 17.8 & 22.4 \\
\hline IX & & & & & & & & & & 65.0 & 19.4 & 25.4 \\
\hline X & & & & & & & & & & & 21.8 & 29.2 \\
\hline XI & & & & & & & & & & & & 34.1 \\
\hline
\end{tabular}

test, the $J$ 's were affected by geographical distance (Fig. 4A) as follows: $\mathrm{y}=-16.1 \operatorname{Ln}(\mathrm{x})+$ $147.9\left(\mathrm{r}^{2}=0.677, \mathrm{P}<0.001, \mathrm{n}=78\right)$; however, the residuals (Fig. 4B) do not show a significant relationship $\left(\mathrm{r}^{2}=0.0015\right)$. On the basis of the similarity matrix (Table 3), we constructed a similarity phenogram (Fig. 5). In agreement with the distribution of pseudovalues, the critical level of similarity (at $\mathrm{P}<0.05$ ) was $J^{*}=24.9 \%$, enabling recognition of three clusters. First, a cluster formed by three regions in northernmost Chile, another comprised by eight centrally-placed regions, and finally a cluster made up of two regions in southernmost Chile (Fig. 5).

\section{DISCUSSION}

Three lines of evidence indicate that the regional distribution and composition of naturalized plants in Chile are geographically ordered. First, the plant turnover ( $\beta$-diversity values) shows a significant aggregation and spatial auto-correlation due to geographical distance. Second, the floristic similarities between regions yield a similar trend, showing that the composition of naturalized plants are not randomly distributed among regions. Third, the phenogram of similarity combined with the bootstrapping procedure displays three geographical assemblages: Northernmost, Central, and Southernmost.

Rejmánek (2000) reported that distant states in the United States of America show a higher level of floristic similarity in exotic flora than nearby states. McKinney (2004a, 2004b, 2005) reported that the presence of alien plants leads to higher total floristic similarity at a regional scale in North America. Similarly, in Chile geographical distance is negatively related to floristic similarity in naturalized plants, but with a different functional relationship: it is non-linear and declines more abruptly than in the USA, where it shows a linear relationship (Fig. 4 versus Fig. 1 in McKinney 2004b). Probably these differences are due to geographical scale, because the study in the USA comprised 1,600 miles across latitude (about 2,000 km) while our study in Chile comprised $5,000 \mathrm{~km}$ in latitudinal extent. Coincidentally, both in Chile and USA when 


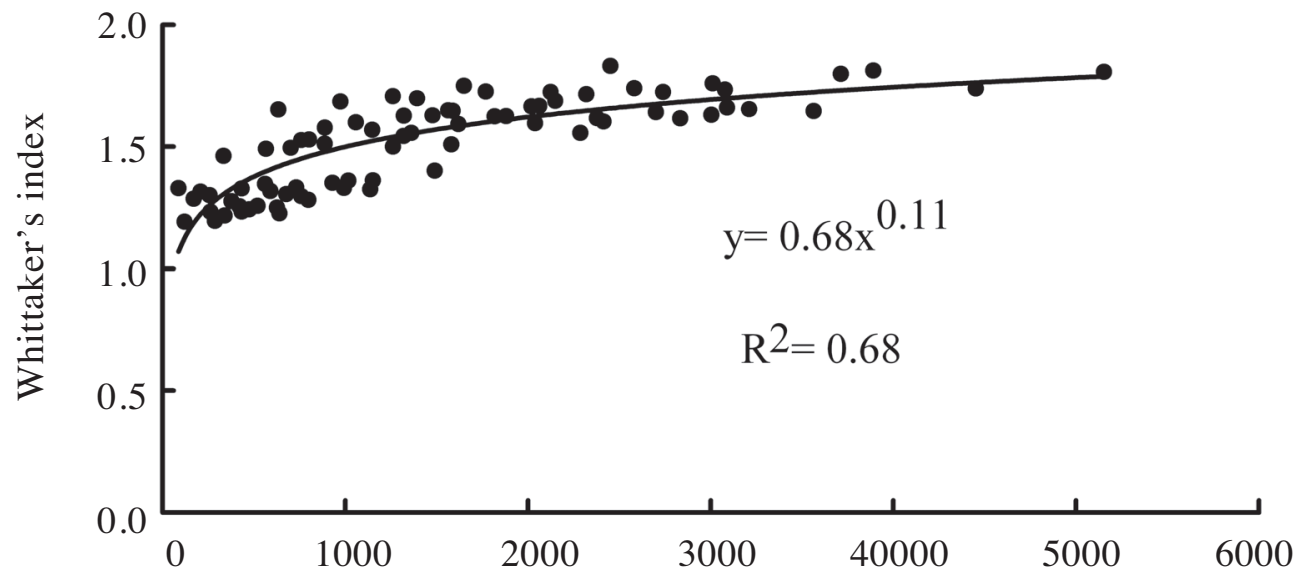

Geographical distance $(\mathrm{km})$

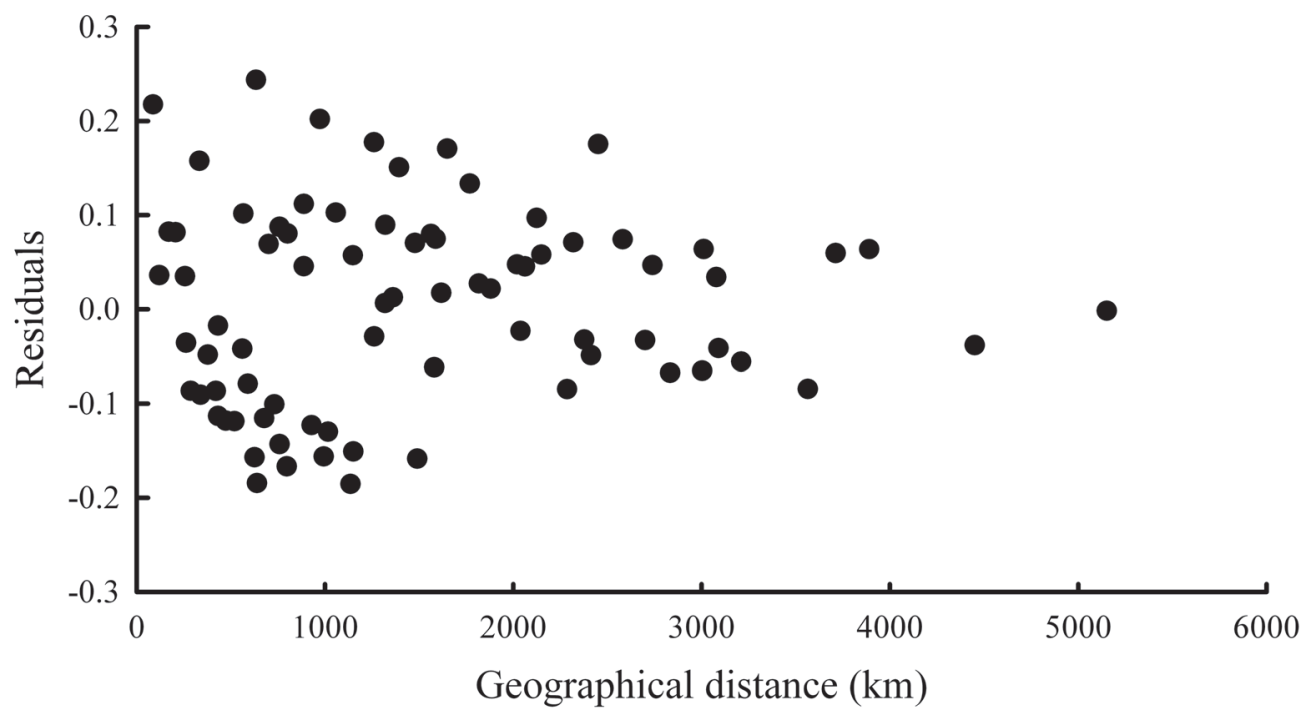

Fig. 3: Turnover (Whittaker's index, W) of naturalized plants among administrative regions in Chile according to geographical distance (A). Residual values are shown in (B).

Recambio (índice de Whittaker, W) de plantas naturalizadas entre regiones administrativas en Chile de acuerdo a la distancia geopolítica (A). Los valores residuales son mostrados en (B).

the effect of distance on similarity pattern is removed, no functional trend is recognized. These results provide quantitative support for the widely held, but rarely quantified, notion that non-native plants show a non-random distribution. Few studies have analyzed the similarity and turnover patterns along geographical scales.

What mechanisms account for the naturalized floristic assemblages observed in Chile? Two hypotheses may be invoked, based on environmental (climate) conditions and on land use by humans. Often these factors have been separately considered in studies of spread and geographical range of invasive species (Deutschewitz et al. 2003, Kowarik 2003, Twiller et al. 2004). However, in Chile the two must be considered simultaneously because the administrative regionalization encapsulates both climatic and European colonization history. For example, assuming that similar sets of alien plants were inoculated throughout Chile, climatic differences correlated with latitudinal gradients along this long stretch of 


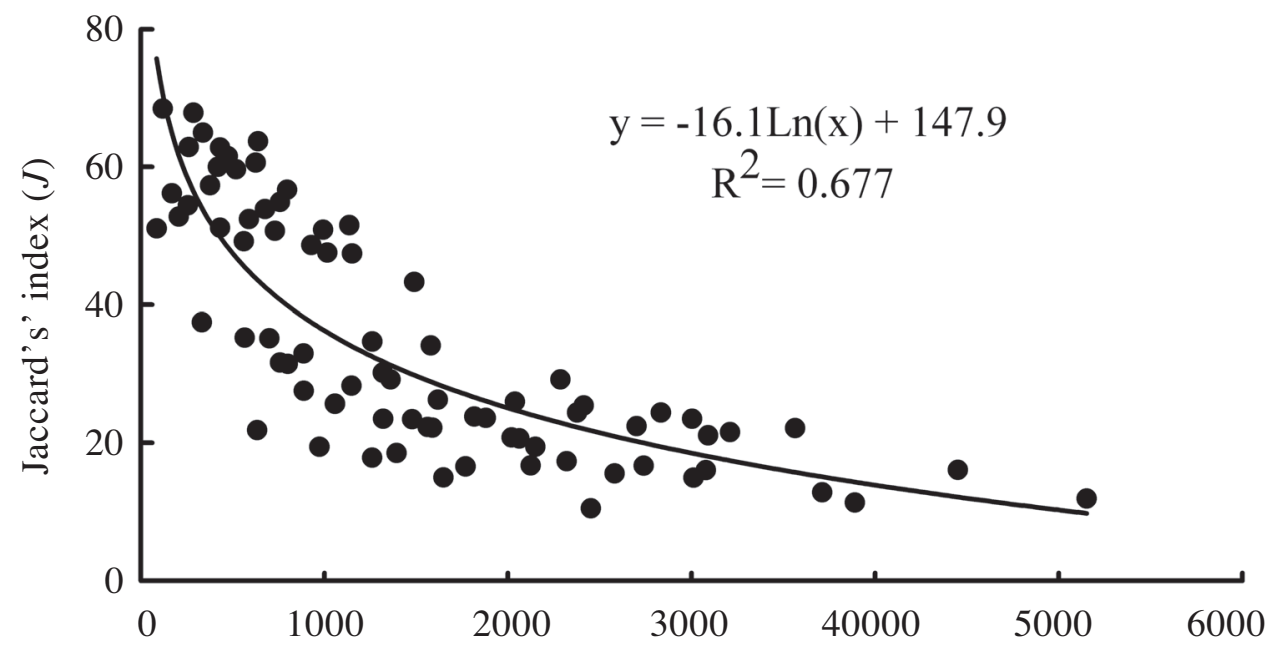

Geographical distance $(\mathrm{km})$

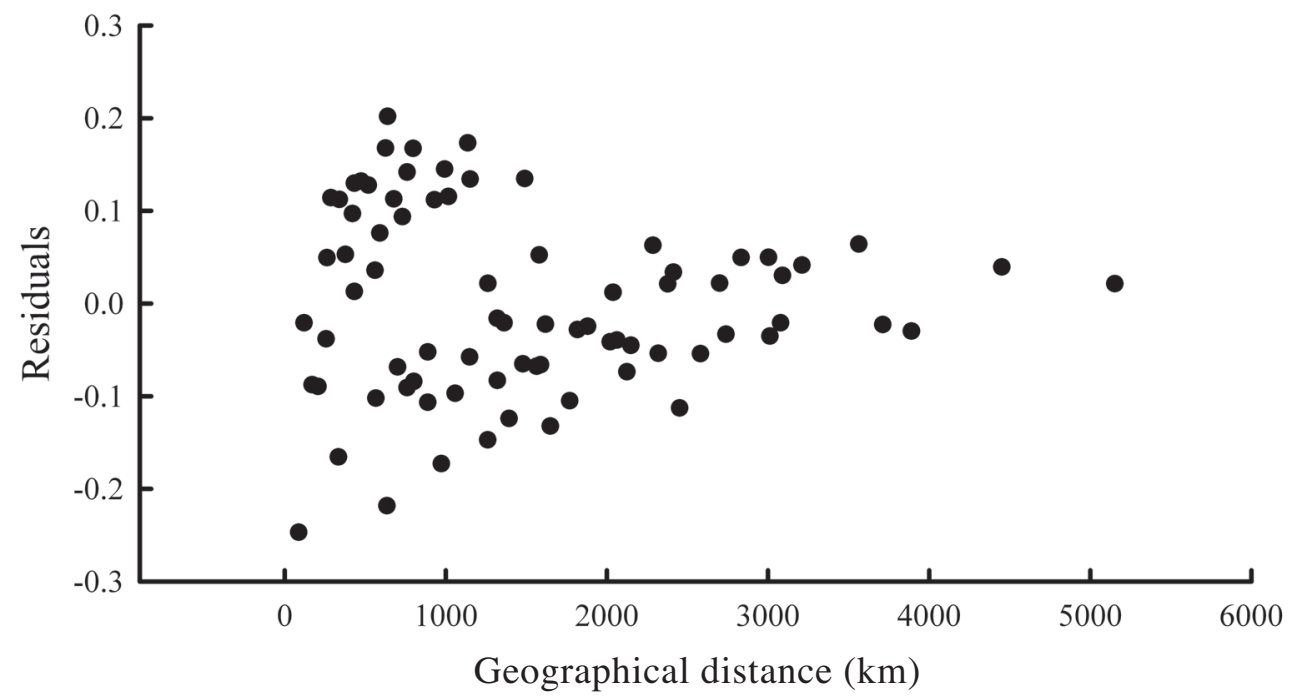

Fig. 4: Similarity (Jaccard's index, $J$ ) of naturalized plants among administrative regions in Chile according to geographical distance (A). Residual values are shown in (B).

Similitud (índice de Jaccard, $J$ ) para la flora naturalizada entre regiones administrativas de Chile de acuerdo a la distancia geográfica (A). Los valores residuales son mostrados en (B).

land would cause differential establishment of naturalized plants (Loehle \& de Blanc 1996, Guisan \& Zimmermann 2000). In favor of this argument, the distinct naturalized plant assemblages detected in Chile are within regions that share similar bioclimatological conditions (di Castri \& Hajek 1976, Gajardo 1994): the Atacama Desert covers Regions IIII, the mediterranean-type formations and temperate forests lie within Regions IV-X, and the Patagonian temperate forests and steppes are present in Regions XI-XII (Gajardo 1994).

On the other hand, naturalized plant assemblages are associated to distinctive land uses as well, emphasizing the importance of human influence (cultural effects, sensu Kowarik 2003) in facilitating the establishment of alien plants. In fact, the regional assemblages of naturalized plants in Chile coincide with geopolitical history, including 


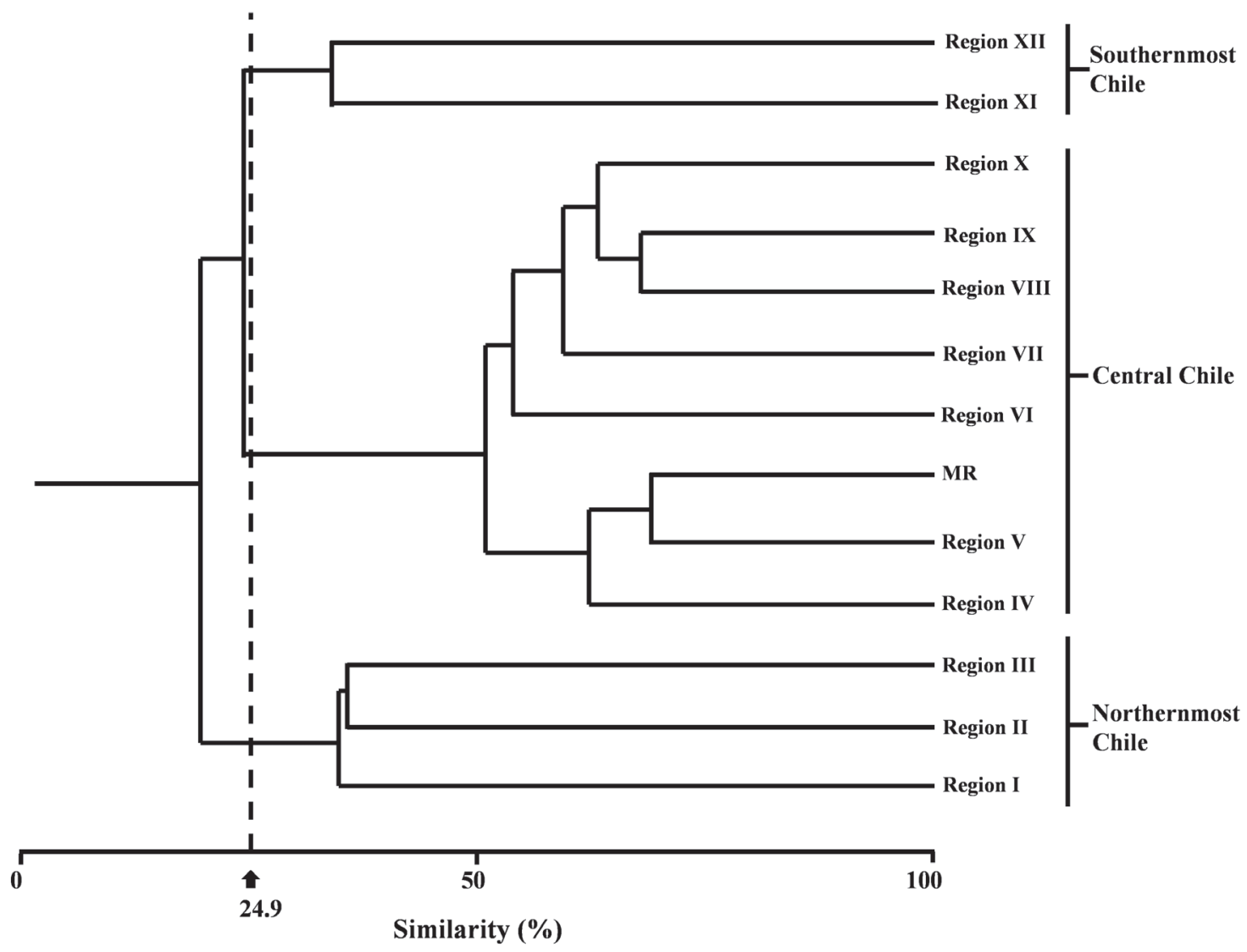

Fig. 5: Similarity phenogram for continental Chile showing naturalized plant clustering.

Fenograma de similitud para las regiones administrativas de Chile continental.

patterns of European colonization, population size, and land use. The first Spanish settlements occurred in central Chile, developing similar agricultural and cattle ranching practices, and currently, this part of the country concentrates most of the exotic weeds (Fig. 2; Matthei 1995, Arroyo et al. 2000). The economic development of Regions I to III has been linked to mining, whereas the land use of southernmost Chile has principally been sheep ranching.

How the species richness is organized within administrative regions (on a landscape scale) is an open question. Studies in Europe and North America show that the richness of naturalized plants is higher in anthropogenic habitats, associated to processes of urbanization (Klotz 1990, Rapoport 2000, McKinney 2002, Deutschewitz et al. 2003, Rodgers \& Parker 2003). In those continents there is correlation among alien richness and area, latitude, and human density at diverse spatial scales (Sukopp et al. 1990, 1995, Pyšek 1998a, 1998b, Rapoport 2000, Araújo 2003). In Chile a similar situation has been observed, emphasizing the importance of human influence and urban settlements on the richness of naturalized plants (Arroyo et al. 2000, Sax 2002, Figueroa et al. 2004, Pauchard et al. 2005). Nevertheless, geographical similarity and richness patterns are not necessarily connected spatially; thus, our main focus in this article (similarity and turnover patterns) constitutes a phenomenon that needs additional analysis of causal relationships.

We conclude that the set of naturalized plants in Chile exhibit a non-random geographical distribution. The regions studied synthesize differences in environment conditions and in land use by European colonization, resulting in an ordered geographical pattern across the country. 


\section{ACKNOWLEDGMENTS}

S.A. Castro thanks Paola Comte and Camilo A. Castro-Comte for helping in data transcription. This work was supported by FONDECYT 3060015, and grants from the A. W. Mellon Foundation and the Center for Advanced Studies in Ecology \& Biodiversity. Aaron Mann (Departamento de Ecología, Pontificia Universidad Católica de Chile) reviewed our manuscript.

\section{LITERATURE CITED}

ARAÚJO MB (2003) The coincidence of people and biodiversity in Europe. Global Ecology and Biogeography 12: 5-12.

ARROYO MTK, C MARTICORENA, O MATTHEI \& L CAVIERES (2000) Plant invasions in Chile: present patterns and future predictions. In: Mooney HA \& RJ Hobbs (eds) Invasive species in a changing world: 385-421. Island Press, Covelo, California, USA.

BLACKBURN TM \& KJ GASTON (2003) Macroecology: concepts and consequences: the $43^{\text {rd }}$ annual symposium of the British Ecological Society. Blackwell Publishing, London, United Kingdom. $442 \mathrm{pp}$.

BROWN JH \& MV LOMOLINO (1998) Biogeography. Sinauer Associates, Sunderland, Massachusetts, USA. 692 pp.

CASTRO SA, JA FIGUEROA, M MUÑOZ-SCHICK \& FM JAKSIC (2005) Minimum residence time, biogeographic origin, and life cycle as determinants of geographic distribution of naturalized plants in continental Chile. Diversity and Distributions 11: 183-191.

CHAPIN III FS, ES ZAVALETA, VT EVINER, RL NAYLOR, PM VITOUSEK, HL REYNOLDS, DU HOOPER, S LAVOREL, OE SALA, SE HOBBIE, MC MACK \& S DÍAZ (2000) Consequences of changing biodiversity. Nature 405: 234-242.

DEUTSCHEWITZ K, A LAUSCH, I KUHN \& S KLOTZ (2003) Native and alien plant species richness in relation to spatial heterogeneity scale in Germany. Global Ecology and Biogeography 12: 299-311.

DI CASTRI F \& E HAJEK (1976) Bioclimatología de Chile. Vicerrectoría Académica, Pontificia Universidad Católica de Chile, Santiago, Chile. 129 pp.

FIGUEROA JA, SA CASTRO, PA MARQUET \& FM JAKSIC (2004) Exotic plant invasions to the mediterranean region of Chile: causes, history and impacts. Revista Chilena de Historia Natural 77: 465-483.

GAJARDO R (1994) La vegetación natural de Chile: clasificación y distribución geográfica. Editorial Universitaria, Santiago, Chile. 165 pp.

GAY C (1845-1854) Historia física y política de Chile. Botánica (Flora chilena). Volume I (496 pp.), volume II (534 pp.), volume III (484 pp.), volume IV (516 pp.), volume V (479 pp.), volume VI (551 pp.), volume VII (515 pp.), volume VIII (448 pp.). Editorial Faine \& Thunot, Paris, France.
GUISAN A \& NE ZIMMERMANN (2000) Predictive habitat distribution models in ecology. Ecological Modelling 135: 147-499.

KLOTZ S (1990) Species/area and species/inhabitants relations in European cities. In: Sukopp H, S Hejny \& I Kowarik (eds) Urban ecology and plant communities in urban environments: 99-104. Academic Publishing, The Hague, The Netherlands.

KOWARIK I (2003) Human agency in biological invasions: secondary releases foster naturalization and population expansion of alien plant species. Biological Invasions 5: 293-312.

LOEHLE C \& D DE BLANC (1996) Model-based assessments of climate change effects on forests: a critical review. Ecological Modelling 90: 1-31.

LONSDALE WM (1999) Global patterns of plant invasions and the concept of invasibility. Ecology 80: $1522-1536$.

MACK RN, D SIMBERLOFF, WM LONSDALE, H EVANS, M CLOUT \& FA BAZZAZ (2000) Biotic invasions, causes, epidemiology, global consequences, and control. Ecological Applications 10: 689-710.

MANLY BFJ (1991) Randomization and Monte Carlo methods in biology. Chapman and Hall, London, United Kingdom. 281 pp.

MARTICORENA C, O MATTHEI, R RODRÍGUEZ, MTK ARROYO, M MUÑOZ, F SQUEO \& G ARANCIO (1998) Catálogo de la flora vascular de la Segunda Región (Región de Antofagasta), Chile. Gayana Botánica (Chile) 55: 23-83.

MARTICORENA C, FA SQUEO, G ARANCIO \& M MUÑOZ (2001) Catálogo de la flora vascular de la IV Región de Coquimbo. In: Squeo A, G Arancio \& JR Gutiérrez (eds) Libro Rojo de la flora nativa y de los sitios prioritarios para su conservación: Región de Coquimbo: 105-142. Ediciones Universidad de La Serena, La Serena, Chile.

MATTHEI O (1995) Manual de las malezas que crecen en Chile. Alfabeta Impresores, Santiago, Chile. 545 pp.

MCGARIGAL K, S STAFFORD \& S CUSHMAN (2000) Multivariate statistics for wildlife and ecology research. Springer-Verlag, New York, New York, USA. 279 pp.

MCNEELEY JA (2001) The great reshuffling: human dimensions of invasive alien species. IUCN, Gland, Switzerland and Cambridge, United Kingdom. 242 pp.

MCKINNEY ML (2004a) Do exotics homogenize or differentiate communities? Roles of sampling and exotic species richness. Biological Invasions 6 : 495-504.

MCKINNEY ML (2004b) Measuring floristic homogenization by non-native plants in North America. Global Ecology and Biogeography 13: 4753.

MCKINNEY ML (2005) Species introduced from nearby sources have a more homogenizing effect than species from distant sources: evidence from plants and fishes in the USA. Diversity and Distributions 11: $367-374$

MCKINNEY ML (2006) Do human activities raise species richness? Contrasting patterns in United States plants and fishes. Global Ecology and Biogeography 11: 343-348.

MCKINNEY ML \& JL LOCKWOOD (1999) Biotic homogenization: a few winners replacing many losers in the next mass extinction. Trends in Ecology and Evolution 14: 450-453. 
OLDEN JD (2006) Biotic homogenization: a new research agenda for conservation biogeography. Journal of Biogeography 33: 2027-2039.

PAUCHARD A, M AGUAYO, E PEÑA \& R URRUTIA (2006) Multiple effects of urbanization on the biodiversity of developing countries: the case of a fast-growing metropolitan area (Concepción, Chile). Biological Conservation 127: 272-281.

PYŠEK P (1998a) Alien plants in Czech village flora: an analysis of species numbers. Feddes Repertorium 109: 39-146.

PYŠEK P (1998b) Alien and native species in Central European urban floras: a quantitative comparison. Journal of Biogeography 25: 155-163.

PYŠEK P, DM RICHARDSON, M REJMÁNEK, G WEBSTER, M WILLIAMSON \& J KIRSCHNER (2004) Alien plants in checklists and floras: towards better communication between taxonomists and ecologists. Taxon 53: 131-143.

RAPOPORT EH (2000) Remarks on the biogeography of land invasions. Revista Chilena de Historia Natural 73: 367-380.

REICHE K (1896-1911) Flora de Chile. Volume I (381 pp.), volume II (397 pp.), volume III (427 pp.), volume IV (489 pp.), volume V (463 pp.), volume VI (176). Imprenta Cervantes, Santiago, Chile.

REJMÁNEK M (2000) A must for North American biogeographers. Diversity and Distributions 6: 208211.

RODGER III JC \& KC PARKER (2003) Distribution of alien plant species in relation to human disturbance on the Georgia Sea islands. Diversity and Distributions 9: 385-398.

ROUGET M, DM RICHARDSON, JL NEL, DC LE MAITRE, B EGOH \& T MGIDI (2004) Mapping the potential ranges of major plant invaders in South Africa, Lesotho and Swaziland using climatic suitability. Diversity and Distributions 10: 475-484.

SALA OE, FS CHAPIN III, JJ ARMESTO, E BERLOW, J BLOOMFIELD, R DIRZO, E HUBER-SANWALD, LF HUENNEKE, RB JACKSON, A KINZIG, R LEEMANS, DM LODGE, HA MOONEY, M OESTERHELD, N POFF, MT SYKES, BH WALKER, M WALKER. \& DH WALL (2000)
Global biodiversity scenarios for the year 2100 . Science 287: 1770-1774.

SAX DF \& SD GAINES (2003) Species diversity: from global decreases to local increases. Trends in Ecology and Evolution 18: 561-566.

SAX DF (2001) Latitudinal gradients and geographic ranges of exotic species: implications for biogeography. Journal of Biogeography 28: 139150 .

SAX DF, SD GAINES \& JH BROWN (2002) Species invasions exceed extinctions on island worldwide: a comparative study of plants and birds. American Naturalist 160: 766-783.

SAX DF (2002) Native and naturalized plant diversity are positively correlated in scrub communities of California and Chile. Diversity and Distributions 8: 193-210.

SUKOPP H, S HEJNY \& I KOWARIK (eds) (1990) Urban ecology: plants and plant communities in urban environments. SPB Academic Publishing, The Hague, The Netherlands. $282 \mathrm{pp}$

THUILLER W, MB ARAÚJO \& S LAVOREL (2004) Do we need land-cover data to model species distributions in Europe? Journal of Biogeography 31: 353-361.

VERMEIJ GJ (2005) Invasion as expectation: a historical fact of life. In: Sax DF, JJ Stachowitz \& SD Gaines (eds) Species invasions: insights into ecology, evolution, and biogeography: 318-339. Sinauer Assocattes Inc. Publishers, Sunderland, Massachusetts, USA.

VITOUSEK PM (1992) Global environmental change: an introduction. Annual Review of Ecology and Systematics 23: 1-14

VITOUSEK PM, CM D'ANTONIO, LL LOOPE \& R WESTBROOKS (1996) Biological invasions as global environmental change. American Scientist 84: 468-478

WEBSTER R \& M OLIVER (eds) (2001) Geostatistical for environmental. John Wiley and Sons Ltd., Chichester, New York, USA. 271 pp.

WIENS JJ \& MJ DONOGHUE (2004) Historical biogeography, ecology and species richness. Trends in Ecology and Evolution 19: 639-644. 
